\title{
'N MODEL VIR KWALITATIEWE NAVORSING IN DIE VERPLEEGKUNDE
}

\section{A. Botes}

\begin{abstract}
Thastione

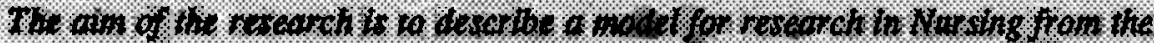

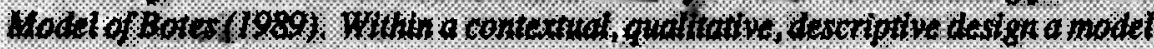

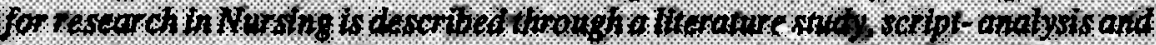

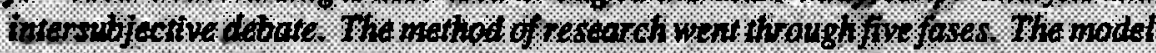

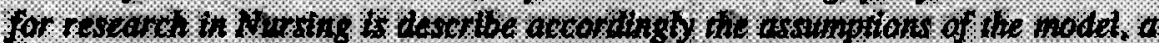

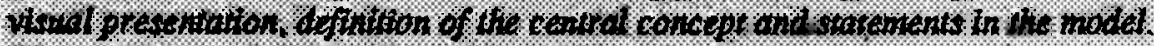

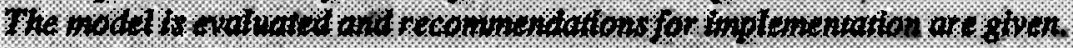

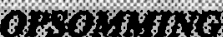

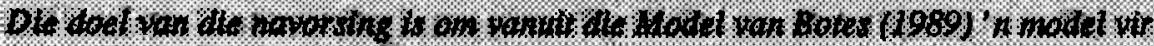

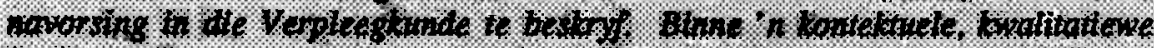

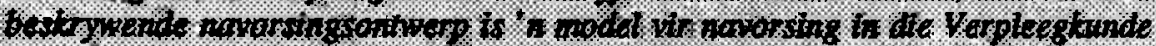

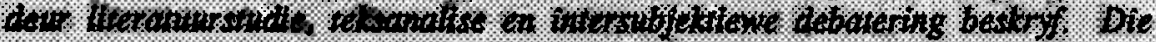

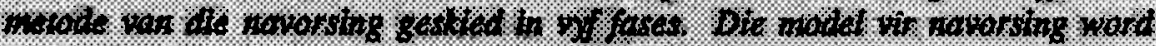

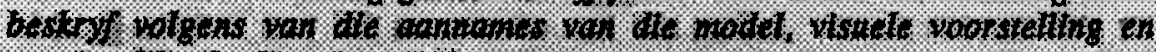

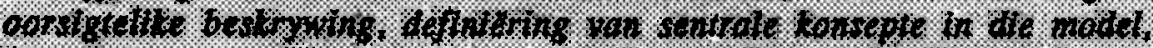

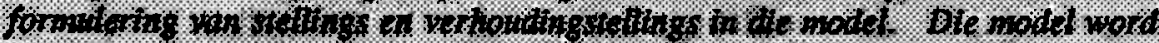

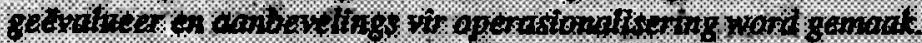

\section{AGTERGROND, RASIONAAL EN PROBLEEMSTELLING}

Vanuit 'n transendentaal-empiriese benadering beskryf Botes (1989) 'n model vir wetenskapsbeoefening in die Verpleegkunde (figuur 1). Hierdie model kan kortliks soos volg beskryf word:

\section{Aannames van die model}

Die anname word gemaak dat wetenskapsbeoefening in die Verpleegkunde vanuit 'n funksionele denkbenadering moet geskied. Dit beteken dat die doel van wetenskapsbeoefening in die Verpleegkunde is om binne ' $n$ bepaalde konteks handelingsgerigte voorskrifte vir toepassing en verbetering van die verplegingspraktyk te gee. Die bruikbaarheid en nuttigheid van navorsingsbevindings om die verplegingspraktyk te verbeter geld as briterium vir geldigheid.

Verder word aanvaar dat navorsing en teorievorming (tweede orde altiwiteite) nie in isolasie plaasvind nie maar in verhouding met die verplegingpraktyk (eerste orde aktiwiteit) en die filosofie van Verpleegkunde (derde orde aktiwiteit).

\section{Metode van die navorsing}

Vanuit 'n transendentaal-empiriese benadering vir die beskrywing van 'n model vir wetenskapsbeoefening in die Verpleegkunde is die volgende metodiek gevolg.

- 'n Empiriese studie is gedoen om die kenmerke van die verplegingspraktyk as navorsingsdomein van Verpleegkunde te beskryf deur tegnieke van teksanalise, woordanalise en sintese asook intersubjektiewe debatering as kontrole stap vir geldigheid.

- As teoretiese raamwerk vir die model is navorsingsmetodologie veral vanuit die teoretiese perspeltiewe van Mouton en Marais (1988) en Smith (1988) bestudeer.

- Vanuit 'n transendentale benadering is die metodologiese implikasies van ' $n$ verskeidenheid wetenskapsfilosofiese modelle vir die Verpleegkunde verken en beskryf.

- Die yoorwaarde en 'n model vir wetenskapsbeoefening in die Verpleegkunde is vanuit hierdie transendentaal-empiriese benadering beskryf.

O Oorsigtelike beskrywing van die model

Die navorser wat op die tweede orde werksaam is selekteer vanuit die derde orde aannames vir sy navorsingsprojek. Hierdie aannames gee gestalte aan die navorsingsstrategie en navorsingsdoelstelling wat as determinante vir navorsingsbesluite optree. Daar word onderskei tussen navorsing oor eerste orde verskysels en navorsing oor tweede orde verskynsels (teorievorming). In navorsing oor eerste orde verskynsels word die navorsingsbesluite in terme van die navorsingsonderwerp, probleemstelling, konseptualisering, operasionalisering, datainsameling asook data-analise en interpretasie gemaak. In terme van navorsing oor tweede orde verskynsels word die navorsingbesluite gemaak in terme $v$ an watter konstuk (konsep, stelling of teorie) waarmee gewerk gaan word en watter metode (analise, sintese of derivasie) gebruik gaan word. Die verband tussen navorsing en teorievorming word aangedui as die konstrukte (stellings) wat as resultaat $v$ an navorsing oor eerste orde verskynsels wat weer in navorsing oor tweede orde verskynsels georden word tot modelle en teorieè.

Die navorser is tydens die uitvoer van die navorsingstaak in dialektiese interaksie met die verplegingspraktyk as navorsingsdomein van Verpleegkunde. Die verplegingspraktyk beskik oor kenmerke wat bepalend is vir die determinante asook die navorsingsbesluite wat geneem word. Die navorser moet verder kennis neem van die leke-interpretasies van die verpleegkundige en die pasiënt aangesien die interpretasies die handelinge van die verpleegkundige en die pasiënt bepaal.

Die probleme wat met die model ondervind word is geleë in die ingewikkeldheid en gevolglike verstaanbaarheid van die model. Verder is die konseptualisering binne die model vreemd binne die tradisonele navorsingsmetodologie in die Verpleegkunde. Dit is belangrik dat 'n eenvormige model vir die onderrig en begeleiding van navorsers gebruik word. Die verbintenis tot ' $n$ bepaalde model of teorie is ook belangrik vir toekomstige akkreditering van verpleegskole.

\section{DIE DOEL MET DIE NA VORSING}

Die doel met die navorsing is om die model $v$ an wetenskapsbeoefening in die Verpleegkunde (Botes, 1989), met spesifieke fokus op die tweede orde, te vereenvoudig en aan te pas sodat dit kongruent is met die konseptualisering in navorsingsmetodologie 


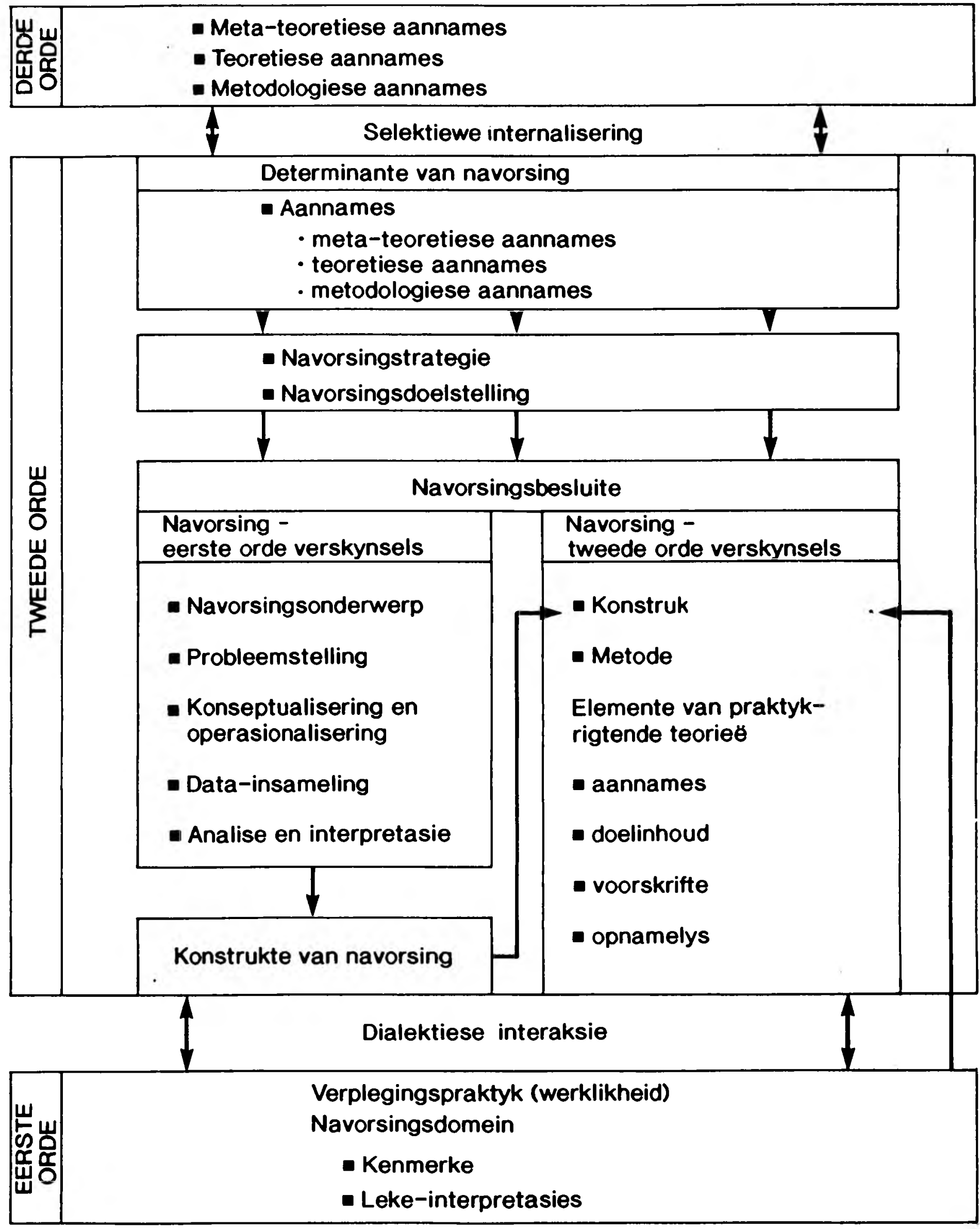

FGUUR 1: 'N MODEL VIR WETENSKAPSBEOEFENING IN DIE VERPLEEGKUNDE 


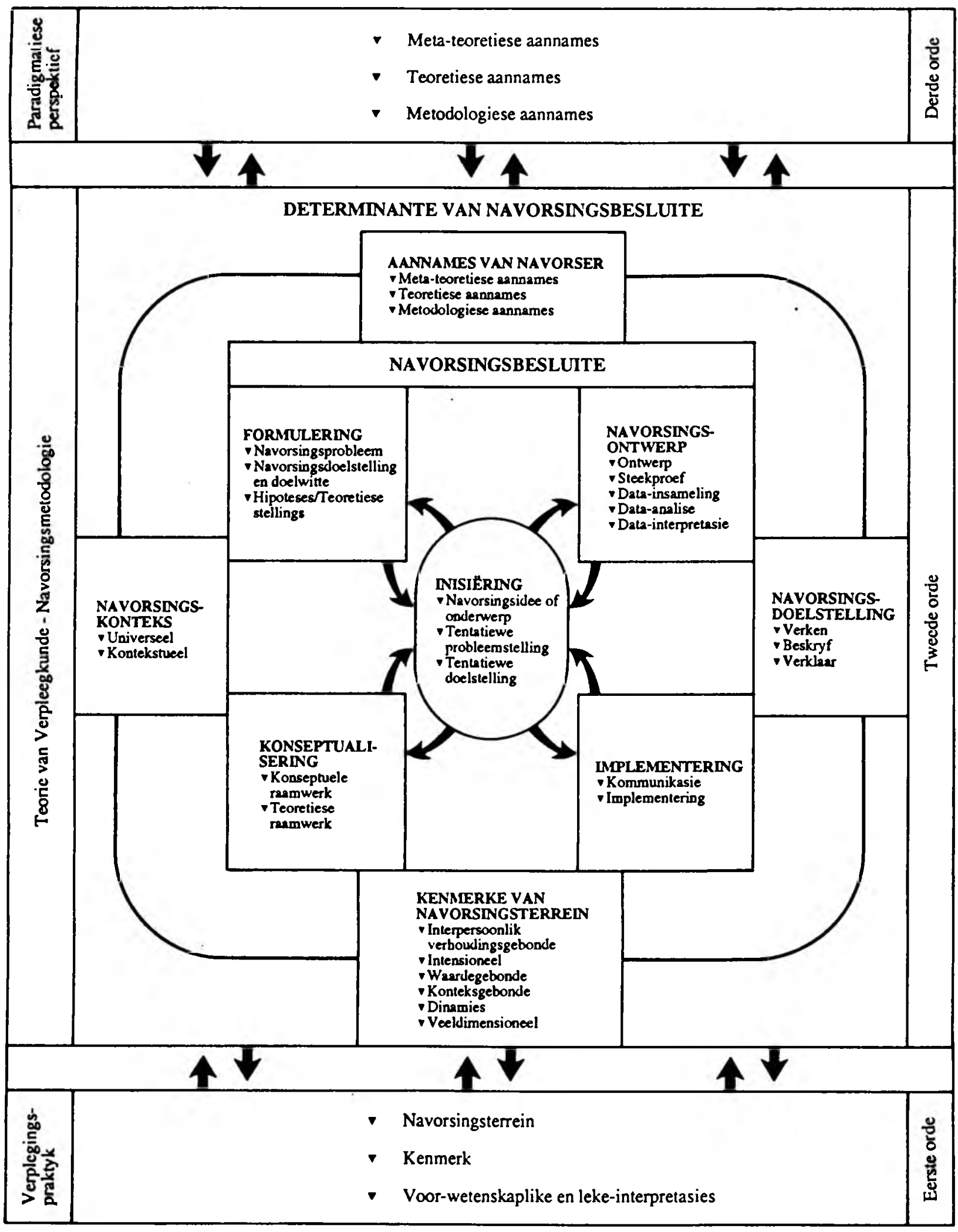

FIGUUR 2: 'N MODEL VIR NAVORSING IN DIE VERPLEEGKUNDE 
in die Verpleegkunde. Die doel met die navorsing is dus om vanuit die model van Botes (1989) 'n model vir navorsing in die Verpleegkunde te beskryf.

\section{METODE VAN DIE NAVORSING}

Binne 'n kontekstuele, kwalitatiewe, beskrywende navorsingsontwerp is die model vir navorsing in die Verpleegkunde deur literatuurstudie, teksanalise en intersubjektiewe debatering beskryf. Die volgende fases in die metode van die navorsing kan beskryf word:

\section{Fase 1}

$\mathrm{Na}$ die beskrywing van die model vir wetenskapsbeoefening in die Verpleegkunde (Botes, 1989) is die model in teorievorming en navorsingsmetodologie binne 'n spesifieke konteks geoperasionaliseer. Uit hierdie ervaring het die probleem van verstaanbaarheid en verwarring oor die verskille in die konseptualisering duidelik geword. Om meer duidelikheid oor die probleem te verkry is daar oorgegaan na die volgende fase.

\section{Fase 2}

Die model van 1989 is skriftelik en mondelings binne groepsverband an die totale populasie binne 'n spesifieke konteks vir kritiese kommentaar beskryf. Die skriftelike data is deur die tegniek van teksanalise ontleed. Kritiese debatering is oor die probleemareas gevoer.

\section{Fase 3}

Konseptualisering deur die bestudering van verpleegkundige literatuur oor navorsingsmetodologie is gedoen om meer duidelikheid oor die konsepte in die model te verkry.

\section{Fase 4}

Uit die vorige fases is ' $n$ voorlopige model vir navorsing in die Verpleegkunde beskryf en weer eens skriftelik aan die totale populasie binne die bepaalde konteks gegee vir kritiese bestudering. Teksanalise en kritiese debatering is gebruik vir die ontleding van die data.

\section{Fase 5}

'n Model vir navorsing in die Verpleegkunde is deur inferensie uit die data van die vorige fases beskryf.

\section{POPULASIE EN STEEKPROEF}

Die totale doserende populasie $(n=11)$ van ' $n$ spesifieke opleidingskool in Verpleegkunde is by die navorsing ingesluit met die oog op teksanalise en intersubjektiewe debatering. $V$ an die persone in die populasie het $n=7$ oor die graad Doktor in die Verpleegkunde beskik en $n=4$ oor ' $n$ magistergraad in
Verpleegkunde. In die realisering van fase 2 het agt $(n=8)$ skriftelike kommentaar gelewer. elf $(n=11)$ het aan gesamentlike en drie $(n=3)$ aan individuele debatvoering deelgeneem.

In fase 4 het ses $(n=6)$ skriftelike kommentaar gelewer en vier $(n=4)$ het an individuele debatvoering deelgeneem.

\section{BEVINDINGS EN INTERPRETASIE VAN DIE NAVORSING}

Bevindings na fase een, twee en vier van die navorsing

Die volgende data het uit die teksanalise en kritiese debatering geblyk:

Die semantiese duidelikheid en konsekwentheid asook die eenvoud van die model is gekritiseer. Konsepte wat problematies blyk te wees is die volgende, naamlik, navorsingsmetodologie, navorsingsontwerp, teorievorming. navorsingsdoelstelling, navorsingstrategie en aannames.

\section{'N MODEL VIR NAVORSING IN DIE VERPLEEGKUNDE}

Vanuit die data van die eerste vier fases van die navorsing is 'n model vir navorsing in die Verpleegkunde deur inferensie beskryf. In die beskrywing van die model sal die volgende aspekte aangespreek word, naamlik die aannames van die model, visuele voorstelling en oorsigtelike beskrywing, definiëring van die sentrale konsepte in die model, stellings en verhoudingstellings in die model asook evaluering van die model.

\section{Aannames van die Model}

Die aannames waarop die model vir navorsing in die Verpleegkunde gegrond is word as meta-teoreties, teoreties en metodologies gestel:

\section{Meta-teoretiese aannames}

In hierdie model word daar vanuit Judeo-Christo asook Bybelse beginsels en waardes vertrek.

\section{Teoretiese aannames}

Die model vir navorsing in die Verpleegkunde is beskryf met die Verplegingsteorie vir Mensheelheid (1991) as raamwerk. Verder vertrek hierdie model vanuit die teoretiese perspektiewe van die model vir wetenskapsbeoefening (Botes, 1989) en 'n verskeidenheid verpleegkundige literatuur oor navorsingsmetodologie soos in die bibliografie uiteengesit.

\section{Metodologiese aannames}

'n Funksionele denkbenadering in die Verpleegkunde word aanvaar. Hierdie denkbenadering impliseer dat die doel van navorsing in die Verpleegkunde is om handelingsgerigte voorskrifte binne 'n bepaalde konteks vir die toepassing en verbetering van die verplegingspraktyk te gee.
Teorievorming is die hoofdoel van navorsing in die Verpleegkunde. Dit beteken dat die losstaande stellings oor ' $n$ bepaalde verskynsel in verpleging rigtinggewend georden moet word deur die generering en toetsing $v$ an hipoteses in die verplegingspraktyk. Vanuit hierdie teoriekan handelingsgerigte voorskrifte vir die verplegingspraktyk gegee word. Die navorser is mede-verantwoordelik vir die verplegingspraktyk.

Visuele roorstelling en oorsigtelike beskrywing van die model

Die model vir navorsing in die Verpleegkunde word deur figuur 2 voorgestel. Die model is van toepassing op kwantitatiewe en kwalitatiewe navorsingsontwerpe asook op teorievorming. Die aktiwiteite van verpleging word op drie vlaldke of ordes voorgestel. Die aktiwiteite op die drie ordes vind in verhouding tot mekaar plaas.

\section{Eerste orde}

Die eerste orde verteenwoordig die verplegingspraktyk en die aktiwiteite wat hier plaasvind is verpleging. Verpleging is ' $n$ werklike verskynsel en die navorsingsterrein van die Verpleegkunde. Navorsing kan nie sommermeer veralgemeen word nie aangesien die verplegingspraktyk oor kenmerke beskik wat eise in terme van navorsing stel. Hierdie kenmerke van die navorsingsterrein tree as determinant op vir navorsingsbesluite.

Die verpleegkundige konstitueer die verplegingspraktyk deurdat die wyse waarop sy verpleeg gestalte gee aan die verplegingspraktyk soos wat dit in werklikheid bestaan. Alhoewel die meeste verpleegkundige handelinge gegrond is op die kennisinhoud van Verpleegkunde vind daar vele verplegingshandelinge plaas wat op voor-wetenskaplike internretasies berus. Die pasiënt handel volgens leke-interpretasies. Die leke-en voor-wetenskaplike interpretasies berus op ervaring en waardes. Die navorser in Verpleegkunde moet kennis neem van hierdie interpretasies om tot volledige verstaan van die verplegingspraktyk te kom. Die navorser moet hierdie interpretasies krities verken, analiseer en toets om dit deel te maak van die kennisinhoud van Verpleegkunde indien dit geldig sou wees.

Die navorser is voortdurend in dialektiese interaksie met die verplegingspraktyk.

\section{Tweede orde}

Die tweede orde is die teorie en metodologie van Verpleegkunde en die aktiwiteite wat hie ter sprake is navorsing en teorievorming. Die navorsingsproses is inherent 'n rasionele besluitnemingsproses en handel oor die navorsingsbesluite wat geneem word in die uitvoering van die navorsingstaak. Die navorsingsbesluite word binne die raamwerk van die determinante van navorsing geneem. Die kenmerke van die navorsingstertein, die aannames van die navorser, die navorsingsdoelstelling en navorsingskonteks tree as determinante vir navorsingsbesluite op. 
Navorsingsbesluite word in terme van die volgende aspekte gemaak naamlik inisiëring, konseptualisering, formulering, navorsingsontwerp asook kommunikasie en implementering. Die navorsingsbesluite volg nie noodwendig kronologies op mekar nie.

\section{Derde orde}

Die derde orde is die paradigmatiese perspektief. Die navorser internaliseer selektief aannames vanuit die paradigmatiese perspektief vir sy navorsing. Die verskillende aannames verteenwoordig die komponente van 'n paradigma en is meta- teoreties, teoreties en metodologies $v$ an aand.

Sentrale konsepte in die model

Konsepte is die elementêre taallike konstruksies waarmee die werklikheid gekonstitueer word. Vanuit die teoretiese en konseptuele raamwerk van die studie kan die sentrale konsepte in die model soos volg gedefinieer word.

\section{a Paradigma}

'n Paradigma kan beskryf word as 'n verbondenheid aan 'n bepaalde denkrigting wat ' $n$ konstelasie is van 'n bepaalde siening oor die mens en sy samelewing (Botha, 1989:50). Dit dien as ' $n$ algemeen aanvaarde struktuur wat die prosesse en resultaat van navorsing en praktyk organiseer (Chinn \& Jacobs, 1987:205). Binne 'n dissipline is das sprake van meer as een paradigma (Mouton \& Marais, 1988:19). Die aanvaarding van 'n spesifieke paradigma beteken dat die navorser hom aan bepaalde gelowe, sienings of aannames oor die mens en sy samelewing verbind. Hierdie verbintenisse word gemaak in terme van meta-teoretiese, teoretiese en metodologiese aannames wat die komponente van 'n paradigma verteenwoordig.

\section{Q Teorie van Verpleegkunde}

Verpleegkunde is 'n menskundige, kliniese gesondheidswetenskap wat die kennisinhoud vorm vir verpleging. Die doel van Verpleegkunde as wetenskap is funsioneel van aard. Verpleegkunde bestaan uit Algemene, Verloskundige, Psigiatriese en Gemeenskapsverpleegkunde wat voortvloei uit Fundamentele Verpleegkunde en wat om 'n gemeenskaplike kern van Etos en Professionele Praktyk asook Verpleegonderwys en Verpleegbestuur gebou is. Die teoretiese inhoud van Verpleegkunde is binne 'n verpleegkundige raamwerk georden uit die teoretiese insigte van die Geestes-, Natuur-, Biologiese -, Oproeding s- en Bestuurswetenskappe, as hulpwetenskappe, waardeur vollediger gestalte gegee word aan verpleging (Botes, 1989:9).

- 'n Teorie kan gesien word as 'n bevestigde (gevalideerde) stellings $w$ at 'n bepaalde verskynsel in die werklikheid beskryf, vertlaar en voorspel (Botes 1989:168). Dit impliseer dus vlak vier volgens die model van Dickoff, James \& Wiedenbach (1968:420). 'n Model is 'n konseptuele raamwerk wat verskynsels klassifiseer in terme van konstrukte (konsepte, stellings) en die verbande tussen die verskynsels en konstrukte beskryf (Botes, 1989:18).

'n Teorie van Verpleegkunde bestaan uit verskillende modelle en teorießëB oor aspekte van verpleging. Die teorie van Verpleegkunde is die kennisinhoud vir verpleging en word deur die aktiwiteite van navorsing en teorievorming gegenereer.

\section{Q Verplegingspraktyk}

Verpleging is 'n diens wat daarop gerig is om die individu, gesin enbf gemeenskap te help om gesondheid (heelheid) te herstel, bevorder en instand te hou. Die verpleegkundige maak gebruik van die verpleegproses as metode om gesondheid te fasiliteer (Randse Afrikaanse Universiteit, 1991:3).

Die verplegingspraktyk is ' $n$ werklike verskynsel en dui op die tyd-ruimtelike en kultuurkonteks waar verpleging plaasvind. Die doel van verpleging is om gesondheid (heelheid) te fasiliteer. Die ard van verpleging is alle verplegingshandelinge wat gerig is om gesondheid te herstel, te bevorder en in stand te hou. Die konteks van verpleging kan binne of buite ' $n$ hospitaal wees. Die verplegingspraktyk is die navorsingsterrein van Verpleegkunde.

\section{Navorsingsmetodologie}

Navorsingsmetodologie is die navorsingsbesluite wat binne die raamwerk van die determinante van navorsing geneem word om aan die eise van geldigheid en betroubaarheid te voldoen (Botes, 1989:117).

\section{- Navorsing en teorievorming in die Verpleegkunde}

Navorsing in die Verpleegkunde is ' doelgerigte aktiwiteit waardeur die verplegingspraktyk op 'n kritiese, nie-sydige en sistematiese wyse bestudeer word om geldige uitsprake oor verpleging te maak (Botes, 1989:117).

Teorievorming is die voortgesette, dinamiese proses van wetenskapsbeoefening (navorsing) deur die steeds duideliker in fokus bring van die verplegingspraktyk deur analise, sintese en derivasie van konsepte, stellings en teorie(Botes, 1989:118).

\section{Determinante van navorsing}

Die determinante van navorsing bied 'n raamwerk waarbinne navorsingsbesluite geneem word en beïnvloed in ' $n$ meerdere of mindere mate elke navorsingsbesluit wat geneem word (Botes, 1989:123). Die determinante van navorsing word tydens inisiëring geïdentifiseer en verkry gestalte en bevorder die kongruensie en logika van die navorsingsbesluite tot mekaar en verseker die sogenaamde goue draad dwarsdeur die navorsing. Die kenmerke van die navorsingsterrein, aannames van die navorser, navorsingsdoelstelling en navorsingskonteks tree as determinante vir navorsing op.

\section{Die kenmerke van die navorsingsterrein}

Die volgende is kenmerke van die verplegingspraktyk en verplegingshandelinge wat eise in terme van navorsing stel (Botes, 1989:110).

Interpersoonlike verhoudingsgebondenheid en intensionaliteit.

Die mens in sy verhoudingsgebondenheid met intensionele handelinge is dikwels die studieterrein van verpleegkundige navorsing. Die mens reageer op die feit dat hy ondersoek word en dit wat direk waargeneem word is nie noodwendig die volle waarheid nie. Die kenmerk stel hoë eise in terme van data-insameling en spesifiek waarneming.

\section{- Waarde en konteksgebondenheid}

Die navorser in Verpleegkunde moet rekening hou met die waardes binne 'n bepaalde tyd-ruimtelike konteks aangesien menslike handelinge slegs verstaan en geïnterpreteer kan word binne die tyd-ruimtelike en veral waande konteks waarbinne dit plaasvind. Die waardes rig menslike handelinge.

\section{- Dinamiese en veeldimensionele aard}

Die veeldimensionele aard van die verplegingspraktyk bemoeilik dit om al die faktore in verpleging byeen te bring en te orden. Die probleem van 'n te eng uitspraak aangaande verpleging bestaan om die rede. As gevolg van die dinamiese aard van dieverplegingspraktyk moet die voorlopigheid van wetenskaplike uitsprake of stellings erken word.

\section{Aannames van die navorser}

Die navorser selekteer vanuit die paradigmatiese perspektief sekere aannames wat as raamwerk vir die navorsing dien. Die seleksie van annames vind plaas na aanleiding van die navorser se dialektiese interaksie met die navorsingsterrein. Aannames is stellings wat deur die navorser voorgehou word as sy bepaalde geloof of siening van 'n saak (Greeff, 1991:12). Aannames is drie ledig van aard, naamlik:

- Meta-teoretiese aannames wat nie toetsbaar is nie en handel oor die mens en sy samelewing. Die aannames het hul oorsprong in die Filosofie.

- Teoretiese aannames wat wel toetsbaar is en deur die navorser voorgehou word vanwe- die erkende gebruik daarvan in die bepaalde dissipline. Die aannames bevat stellings oor die domeinverskynsel (verplegingspraktyk) en vorm deel van die bestaande teoretiese of konseptuele raamwerk van 'n dissipline. 
- Metodologiese aannames handel oor die navorser se siening oor die aard en struktuur van die wetenskap en navorsing. Hierdie aannames het hul oorsprong in die Wetenskapsfilosofie en handel oor die doel, metodes en kriterium vir geldigheid van navorsing en wetenskap.

\section{Navorsingdoelstelling}

Die navorsingsdoelstelling gee 'n breë aanduiding wat met die navorsing bereik wil word. $\mathrm{Na}$ aanleiding van die interaksie met die navorsingsterrein word daar bepaal of verkenning, beskrywing of verklaring of ' $n$ kombinasie van die drie aangewese is. Om handelingsgerigte voorskrifte vir die praktyk te gee moet verklaring die navorsingsdoelstelling wees. Verkenning en beskrywing as navorsingsdoelstellings is egter nodig voor verklaring $v a n$ die navorsingsterrein moontlik is (Botes, 1989:254).

\section{口 Navorsingskonteks}

Die navorsingskonteks dui op die konteksgebonde of universeelbepaalde belang van die navorsing. 'n Kontekstuele studie se uitsprake is slegs geldig binne die bepaalde tyd-ruimtelike en waarde konteks terwyl 'n universele studie veralgemeen word na in breër populasie van soortgelyke verskynsels. By ' $n$ universele studie is interne en eksterne geldigheid ter sprake terwyl slegs interne geldigheid van belang is by 'n kontekstuele studie (Mouton \& Marais, 1988:51). Binne 'n funksionele denkbenadering is die kontekstuele angewese aangesien handelingsgerigte voorskrifte slegs binne bepaalde tyd-ruimtelike en waarde konteks gegee kan word. Die kennis wat vanuit universele belang gegenereer is dien as vertrekpunt vir die kontekstueel-funksionele denkbenadering.

\section{Navorsingsbesluite}

Navorsing is inherent ' $n$ rasionele denk- en besluitnemingsproses. Navorsingsbesluite word binne die raamwerk van die determinante geneem ten einde aan die eise van geldigheid (teoretiese, metings en inferensiële geldigheid) en betroubaarheid te voldoen. Alhoewel die volgorde waarin die besluite geneem word nie by alle tipe navorsing dieselfde is nie word besluite in die uitvoering van die navorsingstaak oor elk van die volgende aspekte geneem.

\section{U Inisiëring}

Elke navorsing begin met hierdie fase. Tydens die fase besin die navorser oor ' $n$ navorsingsonderwerp of idee. Die bron van die navorsingsonderwerp of idee is die verplegingspraktyk (Polit \& Hungler, 1987:50). Die navorsingsonderwerp of idee moet in terme van die doel, aard en konteks van verpleging bedink en gestel word om te verseker dat dit verpleegkundig relevant is (Botes, 1989:256). Die navorser kan in hierdie fase literatuur oor die navorsingsonderwerp bestudeer. ' $n$ Tentatiewe probleemstelling en doelstelling word gestel. Daar word ook in die fase oor die uitvoerbaarheid $v$ an die navorsing in terme van navorsingskundigheid, tyd, finansies, beskikbaarheid van ondersoekpersone, etiese, metodologiese en ander oorwegings gedink (Burns \& Grove, 1987:118; Wilson, 1989:222). Teen die einde van die fase is die navorser instaat om 'n navorsingsvoorstel voor te lê. Die aannames van die navorser, die navorsingsdoelstelling, navorsingskonteks en kenmerke van die navorsingsterrein (determinante van navorsingsbesluite) word tydens inisiëring geïdentifiseer en verkry gestalte.

\section{Konseptualisering}

In hierdie fase is dit die doel om deur literatuurverkenning 'n konseptuele enbf teoretiese raamwerk vir die studie daar te stel. Verbandhoudende modelle en teorie- kan bestudeer word as deel van die teoretiese raamwerk van die studie. Die konsepte in die navorsingsonderwerp se konotiewe en donotiewe betekenisse moet uitgeklaar word as deel van die konseptuele raamwerk van die studie. In teorievorming word konsepte, stellings en teoriez geanaliseer, gesintetiseer en gederiveer met die hulp van bestaande literatuur. Hierdie fase beinvloed die teoretiese geldigheid (konotiewe betekenis van konsepte) sowel as die metingsgeldigheid (denotiewe betekenis van die konsepte) van die navorsing (Burns \& Grove, 1987:129; Wilson, 1989.281)

\section{a Formulering}

Tydens hierdie fase van navorsingsbesluite formuleer die navorser na 'n literatuur enbof empiriese verkenning die navorsingsprobleem, subprobleme navorsingsdoelstellings en doelwitte. Hierdie formulering is 'n verfyning van die tentatiewe navorsingsprobleem en doelstelling van die inisiëringsfase. Indien dit relevant sou wees vir die studie word een of meer hipotese of die sentrale teoretiese stelling waaroor die navorsing handel, geformuleer (Uys \& Basson, 1991:32; Burns \& Grove, 1987:188).

In die formulering van die navorsingdoelstelling tree die kenmerke van die navorsingsterrein as determinant vir die besluit op deurdat die aard van die navorsingsterrein bepaal of verken, beskryf of verklaar angewese is. Die navorsingsdoelstelling en doelwitte ontwikkel uit die probleemstelling. Die formulering van die navorsingsprobleem word beinvloed deur die navorsingskonteks (universeel of kontekstueel).

\section{a Navorsingsontwerp}

In die navorsingsontwerpfase besluit die navorser oor 'n toepaslike navorsingsontwerp. populasie en steekproef, data-insameling, data-analise en date-interpretasie. Die besluit word bepaal deur die navorsingskonteks en navorsingsdoelstelling as determinante van navorsing. Metings en inferensiële geldigheid asook betroubaarheid van die data moet tydens hierdie navorsingsbesluit verseker word (Bums \& Grove, 1989:433)

\section{Kommunikasie en implementering}

In hierdie fase stel die navorser sy navorsing skriftelik en mondelings bekend. Die volgende aspekte van navorsing moet gekommunikeer word, naamlik die aannames van die navorser, rasionaal, probleemstelling, doelstelling, hipotesesteoretiese stellings, teoretiese enbf konseptuele raamwerk, navorsingsontwerp, populasie en steekproef, data-insameling, data-analise, datainterpretasie, gevolgtrekkings, aanbevelings en evaluering van die navorsing.

Binne ' $n$ funksionele denkbenadering is die navorser mede-verantwoordelik vir die verplegingspraktyk en moet verseker dat modelle en teorieë aan die praktyk bekend gestel, geümplementeer en geëvalueer word (Botes, 1989:211).

\section{STELLINGS EN VERHOUDINGSTELLINGS IN DIE MODEL VAN NAVORSING IN DIE VERPLEEGKUNDE}

In hierdie gedeelte word die verhouding tussen die konsepte in die model deur inferensie in die vorm van stellings en verhoudingstellings uitgedruk. Die sentrale stelling van hierdie model is:

Navorsing gegrond op die model vir navorsing in die Verpleegkunde dra by tot verbetering in die gehalte van die verplegingspraktyk.

Ondersteunend tot hierdie stelling $\mathbf{k}$ an die volgende stellings geformuleer word:

\section{- 'n Funksionele denkbenadering is aangewese vir navorsing in die Verpleegkunde.}

- Die verpleegkundige navorser fasiliteer gesondheid deur navorsing.

- Die aktiwiteite op die drie ordes van verpleging vind nie in isolasie plaas nie. maar staan in verhouding tot mekaar.

- Die determinante van navorsing bied ' raamwerk waarbinne navorsingsbesluite geneem word en verseker so die logiese en kongruente verloop van die navorsing.

- Navorsingsbesluite moet sodanig geneem word sodat daar aan die eise van geldigheid en betroubaarheid voldoen word.

- Die doel van navorsing in die verpleegkunde is teorievorming om handelingsgerigte voorskrifte binne bepaalde konteks vir die verplegingspraktyk te gee. 
Evaluering van die model vir navorsing in die Verpleegkunde

Die betroubaarheid van die model is in fases twee en drie van die navorsing deur intersubjektiewe debatering verseker. Die kriteria van Chinn \& Jacobs (1987: 137-145) word as raamwerk vir die hieropvolgende evaluering van die model gebruik.

\section{Duidelikheid}

Wat die semantiese duidelikheid betref is die aannames van die navorser eksplisiet gestel en dien as raamwerk waarbinne die model gekonseptualiseer is. Meeste konsepte is reeds binne die model vir wetenskapsbeoefening in die Verpleegkunde (Botes, 1989) uitgeklaar en aandag is slegs aan die konsepte wat onduidelik uit fases een, twee en vier geblyk het, gegee. Die navorsingsdoelstellings enersyds as determinant en andersyds as deel van die formuleringsfase mag met die eerste oogopslag onduidelik voorkom maar met verdere bestudering van die model sal die logika, kongruensie en noodsaaklikheid daarvan ingesien word.

Versigtigheid is aan die dag gel+ om die konsekwente gebruik van konsepte in die model te bevorder en sodoende semantiese kongruensie van die model te verseker en aandag is tydens die debatering daaraan gegee.

Wat die struktuele duidelikheid en konsekwentheid betref is aandag gegee aan die logiese koppeling van die konsepte in die model. Die ordening in vlakke of ordes van verplegingsaktiwiteite dra verder by tot struktuele duidelikheid en konsekwentheid.

Eenvoud, algemeenheid en empiriese aanwending

Alhoewel die navorsingsproses nie eenvoudig is nie is die vereenvoudiging van die model van 1989 'n verbetering. Indien daar van die konsepte weggelaat sou word sou dit waarskynlik die duidelikheid van die model belnvloed.

Die model is ' $n$ kontekstuele model en beskik nie noodwendig oor algemeenheid nie. Dit mag egter moontlik wees om die model te veralgemeen.
Aangesien die model vir navorsing gerig is op tweede orde aktiwiteite is die kriterium van empiriese aanwending moeilik om te verantwoord. Vanuit die sentrale stelling van die model behoort die empiriese invloed van die model bepaal te kan word indien daar geldige kriteria vir gehalte in verpleging bestaan.

\section{GEVOLGTREKKING EN \\ AANBEVELINGS VIR OPERASIONALISERING}

Vanuit die debatering kan die gevolgtrekking gemaak word dat die model vir navorsing in die Verpleegkunde makliker as sy voorganger in die onderrig en implementering van navorsing geoperasionaliseer behoort te kan word.

Die model vir navorsing in die Verpleegkunde kan op voorgraadse en nagraadse onderrig van navorsingsmetodologie (navorsing en teorievorming) gebruik word. By die uitvoering van 'n navorsingstaak kan die model as riglyn vir logiese denke gebruik word. Die implementering van die model in die onderrig en begeleiding van navorsers behoort die kommunikasie tussen die lektor in navorsingsmetodologie, die studieleier promotor en die student te vergemaklik aangesien 'n eenvormige raamwerk deurgaans gebruik word.

\section{BIBLIOGRAFIE}

BOTES, AC 1989 : 'n Model vir wetenskapsbeoefening in die Verpleegkunde. Johannesburg, Randse Afrikaanse Universiteit (D. Cur.-proefsirif).

BOTHA, ME 1989 : Theory development in perspective : The role of conceptual Frameworks and Models in theory development. Journal of Advanced Nursing, 14 (1), 1989:49-55.

BURNS, N \& GROVE, SK 1987 : The practice of Nursing Research. Conduct. critique and utilization. London: WB Saunders.
CHINN, PL \& JACOBS, MK 1987 : Theory and nursing. A Systematic approach. Second edition. London: Mosby.

DICKOFF, J; JAMES, P \& WIEDENBACH, E 1968 : Theory in a practice discipline. Part 1. Practice oriented theory. Nursing Besearch 17(5) Sept.-Oct. 1968: 415-435

GREEFF, M 1991 : 'n Model vir Psigiatriese Verpleegkundige begeleiding van die pasi-nt met geestesongemak. Johannesburg: Randse Afrikaanse Universiteit. D. Cur.-proefskrif.

MOUTON, J \& MARAIS, HC 1988 : Metodologie van die geestes wetenskappe : Basiese begrippe. Pretoria : Raad op Geesteswetenskaplike Navorsing.

POLIT, DF \& HUNGLER, BP 1987 : Nursing research, principles and methods. Third Edition. New York : Lippincott.

RANDSE AFRIKAANSE UNIVERSITEIT 1991 : Verplegingsteorie vir Mensheelheid. Johannesburg : Randse Afrikaanse Universiteit.

SMITH, DPJ 1988 : Teorie en praktyk van die opvoedkunde. Johannesburg: Randse Afrikaanse Universiteit (monografie).

UYS, HHM \& BASSON, AA 1991 : Navorsingsmetodologie in die Verpleegkunde. Pretoria: HAUM.

WILSON, HS 1989 : Research in Nursing: Second Edition. New York: Addison-Westley.

\begin{tabular}{|c|}
\hline ANNATJIE BOTES \\
D. CUR. (RAU) M. CUR. (RAU) \\
B. CUR. (UP) B.A. (CUR) (UNISA) \\
RANDSE AFRIKAANSE UNIVERSTEIT \\
Departement Verpleegkunde \\
Randse Afrikaanse Universiteit \\
Posbus S24 \\
JOHANNESBURG \\
2000
\end{tabular}

